\title{
Досвід ендоскопічної мікродискектоміі при грижах міжхребцевих дисків
}

\author{
В. К. Піонтковський ${ }^{1}$, Я. В. Фіщенко ${ }^{2}$, Л. Д. Кравчук ${ }^{2}$ \\ ${ }^{1}$ Рівненська обласна клінічна лікарня, \\ ${ }^{2}$ Інститут травматології та ортопедії НАМН України, м. Київ

\section{Our experience of endoscopic microdiscectomy in hernias of intervertebral discs}

\author{
V. K. Piontkovskyi ${ }^{1}$, Ya. V. Fishchenko ${ }^{2}$, L. D. Kravchuk ${ }^{2}$ \\ ${ }^{1}$ Rivne Regional Clinical Hospital, \\ ${ }^{2}$ Institute of Traumatology and Orthopedics, Kyiv
}

\section{Реферат}

Мета. Оцінити ефективність трансфорамінальної ендоскопічної мікродискектомії, виявити недоліки та переваги даного методу в порівнянні зі стандартними методиками, на основі отриманих даних визначити основні показання та протипоказання до даної процедури.

Матеріали і методи. Проаналізовано 290 історій хвороб пацієнтів з грижами поперекового відділу хребта, які перебували на лікуванні в Обласному центрі ортопедії, травматології та вертебрології Рівненської обласної клінічної лікарні та відділенні хірургії хребта Інституту травматології та ортопедії НАМН України з квітня 2016 по квітень 2018 р. Серед пацієнтів було 156 жінок та 134 чоловіки віком від 20 до 84 років. Усім хворим в передопераційному періоді було проведено магнітно-резонансну (МРТ) або комп’ютерну (КТ) томографію поперекового відділу хребта, функціональну рентгенографію, загально-клінічні обстеження.

Результати. В післяопераційному періоді відповідно до міжнародного опитувача якості життя Oswestry cepeдній показник щодо досліджуваних хворих становив $21,1 \%$, що відповідає доброму результату. Больовий синдром перед операцією за візуально-аналоговою шкалою був оцінений у 8,5 бала, а через 6 міс після операції - у 1,5 бала (переважала люмбалгія і майже не було корінцевого болю). Накопичений значний практичний досвід виконання ендоскопічної трансфорамінальної мікродискектомії засвідчив, що хірург може зіткнутися з певними технічними труднощами у разі краніальної або каудальної міграції секвестру, в ряді спостережень доступ на рівні L5 - S1 затруднений через високе розташування гребеня клубової кістки, але все-таки за наявності правильних показань ця методика дає змогу в короткі строки позбутися компресійного корінцевого синдрому.

Ключові слова: поперековий остеохондроз; грижа міжхребцевого диска; ендоскопічна мікродискектомія.

Abstract

Objective. To estimate the efficacy of transforamenal endoscopic microdiscectomy, to reveal the faults and advantages of this method, comparing with standard procedures, basing on the data obtained, the main indications and contraindications for this procedure must be determined.

Materials and methods. There were analyzed 290 cases of the disease in patients with hernias of lumbar part of vertebral column, who were stationary treated in Regional Centre of Orthopedics, Traumatology and Vertebrology of the Rivne Regional Clinical Hospital and in the Department of Vertebral Surgery of the Institute of Traumatology and Orthopedics NAMS of Ukraine from April 2016 till April 2018 yr. Among them were 156 women and 134 men, ageing 20 - 84 yrs old. Preoperatively in all the patients a magnet-resonance tomography or computeric tomography of lumbar part of vertebral column, functional rentgenography, and general clinical examination were conducted.

Results. In postoperative period in accordance to international questionnaire for the quality of life (Oswestry) a median index, concerning the investigated patients, have constituted $21.1 \%$, what means a good result. Preoperative pain syndrome in accordance to a visual-analogue scale was estimated as 8.5 points, and in 6 mo postoperatively - as 1.5 points (lumbalgia prevailed and a radiculitis pain was almost absent). Significant practical experience of the endoscopic transforamenal microdiscectomy performance have witnessed, that a surgeon may meet a certain difficulties in a case of a sequester cranial or caudal migration, in some observations the operative access on level of L5 - S1 is complicated because of high localization of iliac crest, but if correct indications applied this procedure makes possible to eliminate the compressive radicular syndrome in a short term. Conclusion. Application of transforamenal endoscopic microdiscectomy in treatment of patients with hernias of intervertebral discs have confirmed a quite high efficacy of this procedure and its advantages.

Keywords: transverse osteochondrosis; hernia of intervertebral disc; endoscopic microdiscectomy.

«Золотим стандартом» хірургічного лікування гриж міжхребцевих дисків (МХД) є відкрита мікродискектомія, але останнім часом з'явилися численні методики, автори яких прагнуть мінімізувати травматичність операційного доступу, не знижуючи радикальності операції. Так, на початку 1990-х рр.запропоновано альтернативну методику - ендоскопічну трансфорамінальну мікродискектомію [1 - 6]. Хірурги почали використовувати два основних доступи - латеральний (Richard Wolf) та задньолатеральний (JoyMax, Thesyss, Max More). 
На нашу думку, яка збігається з думкою багатьох авторів [4 - 6], задньолатеральний доступ має ряд переваг: можливість часткової резекції фасетки збільшує простір для ендоскопа та вирішує проблему латерального стенозу, а також уможливлює часткову ревізію міжтілового проміжку, в той час як за чисто бокового підходу можна тільки видалити вільні секвестри з каналу. Якщо довгий час хірурги ставились до цієї методики досить скептично, то сьогодні прихильників ендоскопічної трансфорамінальної мікродискектомії стає дедалі більше, у великій кількості наукових публікацій вказується на значні переваги цієї методики над відкритою хірургією $[7,8]$.

Крім того, ряд хірургів не обмежуються лише мікродискектомією, а застосовують ендоскопічну хірургію для видалення кіст дуговідросчатих суглобів [11] та для лікування різних форм стенозу [9].

Мета дослідження: оцінити ефективність трансфорамінальної ендоскопічної мікродискектомії, виокремити недоліки та переваги даного методу в порівнянні зі стандартними методиками, на основі отриманих даних визначити основні показання та протипоказання до даної процедури.

\section{Матеріали і методи дослідження}

Проаналізовано 290 історій хвороб пацієнтів з грижами поперекового відділу хребта, які перебували на лікуванні в Обласному центрі ортопедіі, травматології та вертебрології Рівненської обласної клінічної лікарні та відділенні хірургії хребта Інституту травматології та ортопедії НАМН України з квітня 2016 по квітень 2018 р. Серед пацієнтів було 156 жінок та 134 чоловіки віком від 20 до 84 років. Усім хворим у передопераційному періоді було проведено МРТ або КТ поперекового відділу хребта, функціональну рентгенографію, загально-клінічні обстеження.

Показаннями до виконання оперативного втручання були: неефективність консервативного лікування компресійного корінцевого синдрому протягом 6-8 тижнів, кауда-синдром, гострий парез ступні, наростання неврологічної симптоматики на фоні консервативного лікування.

У таблиці представлено розподіл пацієнтів відповідно до локалізації грижі МХД за даними МРТ.

Техніка виконання операцї. Оперативне втручання виконували набором Max More, запропонованим T. Hoogland, з використанням хірургічної техніки outside - in [4 - 6].

У положенні хворого на животі робили розмітку для визначення траєкторії входу дилататорів. На рівні L5 - S1 відступали від серединної лінії 12 - 14 см, на рівні L4 - L5 - 10 - 12 см, на рівні L1 - L2 - L3 - L4 - 8 - 10 см, для визначення кута входу проводили траєкторію через верхів- ку латеральної фасетки і основу грижі. Після застосування місцевого знеболювання 2\% розчином лідокаїну встановлювали спінальну голку на верхівку латеральної фасетки, по голці вводили спицю-провідник, по якій вводили м'якотканинні дилататори, голку Tom - Shidi та кісткові розвертки від 4,5 до 9 мм почергово. Усі дії контролювали за допомогою електронно-оптичного перетворювача у двох проекціях.

Після виконання часткової резекції латеральної фасетки трансфорамінально вводили робочу канюлю, по якій вводили ендоскоп з постійною подачею стерильного фізіологічного розчину, попередньо підігрітого до температури тіла, з тиском 80 мм вод. ст.

Після ідентифікації грижового випинання видаляли його за допомогою мікроронжера, а великі секвестри, що не поміщалися в робочий канал ендоскопа, евакуювали разом з оптикою.

Для повного видалення дрібних часточок диска, епідуральних злук та розволокненої задньої поздовжньої зв'язки застосовували радіочастотний електрод Triger - Flex, який приєднували до радіочастотного генератора з робочою температурою на його кінці до $42^{\circ} \mathrm{C}$. Низькотемпературна коагуляція зменшує реакцію навколишніх тканин на втручання і є профілактикою утворення епідурального фіброзу. Позитивною ознакою повної декомпресії корінця вважали наявність пульсації твердої мозкової оболонки та корінця. В післяопераційному періоді проводили контрольну МРТ для верифікації повного видалення грижі.

\section{Результати}

Відповідно до міжнародного опитувача якості життя Oswestry середній показник щодо прооперованих пацієнтів становив 21,1\%, що відповідає доброму результату. Больовий синдром був оцінений за візуально-аналоговою шкалою в передопераційному періоді у 8,5 бала, а через 6 міс після операції - у 1,5 бала з переважанням люмбалгії і з майже повною відсутністю корінцевого болю. Тривалість госпіталізації в середньому становила 3 ліжко-дні, вертикалізацію хворого здійснювали через 2 - 3 год після завершення процедури. В післяопераційному періоді хворим призначали нестероїдні протизапальні препарати, габапентини, периферичні міорелаксанти до 7 днів. Нейротропну терапію рекомендували впродовж 1 міс.

\section{Обговорення}

Варто зупинитися на технічних складнощах та ускладненнях, 3 якими ми зіткнулися.

\begin{tabular}{|c|c|c|c|c|c|c|c|}
\hline \multicolumn{8}{|c|}{ Розподіл хворих відповідно до локалізації грижі МХД (n= 290) } \\
\hline \multirow{2}{*}{\multicolumn{2}{|c|}{ Локалізація }} & \multicolumn{6}{|c|}{ Рівень } \\
\hline & & L1-L2 & L2-L3 & L3-L4 & L4-L5 & L5-S1 & L4-L5-S1 \\
\hline \multicolumn{2}{|c|}{ Серединна } & - & 4 & 2 & 38 & 8 & - \\
\hline \multicolumn{2}{|c|}{ Парамедіанна } & 3 & 6 & 5 & 120 & 55 & 13 \\
\hline \multicolumn{2}{|c|}{ Форамінальна } & - & - & - & 15 & 7 & 7 \\
\hline \multicolumn{2}{|c|}{ Екстрафорамінальна } & - & - & - & - & - & - \\
\hline \multirow[t]{2}{*}{ Всього ... } & абс. & 3 & 10 & 7 & 180 & 70 & 20 \\
\hline & $\%$ & 1,1 & 3,4 & 2,4 & 62,1 & 24,1 & 6,9 \\
\hline
\end{tabular}


1. На початкових етапах освоєння методики у 9 (3,1\%) хворих не була здійснена повна евакуація матеріалу грижового випинання через брак досвіду та значну міграцію секвестру по каналу, що стало причиною повторного виконання оперативного втручання.

2. У 6 (2,1\%) хворих з астенічною тілобудовою на рівні L5 - S1 не вдалося виконати трансфорамінальний доступ через високе стояння крила клубової кістки, що спричинило виконання відкритої операції.

3. У 18 (6,2\%) хворих протягом 6 міс виник рецидив грижі. Даний факт ми пов'язуємо з тим, що методика трансфорамінальної ендоскопічної мікродискектомії не передбачає радикальної ревізії та кюретажу порожнини диска, що може призвести до міграції вільних фрагментів з міжтілового проміжку в хребтовий канал у подалышому. За даними різних літературних джерел $[2,3]$ частота рецидиву грижі диска після відкритої мікродискектомії становила від 3 до 9\%. Наш показник порівнянний з наведеними даними.

У решти 257 (88,6\%) хворих відмічено позитивну динаміку щодо неврологічного дефіциту.

4. У 4 (1,4\%) хворих початкові явища нестабільності через 6 та 8 міс наростали та проявлялися посиленням болю в спині без неврологічного дефіциту, що потребувало виконання транспедикулярної фіксації.

5. Асептичний спондилодисцит розвинувся у $3(1,1 \%)$ хворих, стандартна медикаментозна терапія якого була успішною.

6. У 3 (1,1\%) хворих сталося інтраопераційне пошкодження твердої мозкової оболонки, на нашу думку, через наявність епідурального спайкового процесу внаслідок тривалої хвороби та виражений центральний стеноз хребтового каналу. Для профілактики ліквореї було застосовано губку ТахоКомб та накладання глибокого шва на рану. Дане ускладнення ніяк не відобразилось на результатах лікування, а його частота не вища, ніж після виконання стандартної мікродискектомії.

Посилаючись на наведене, можна визначити основні показання до виконання ендоскопічної трансфорамінальної мікродискектомії: наявність грижі МХД на будьякому рівні поперекового відділу хребта з наявністю компресійного корінцевого синдрому, що не піддається консервативному лікуванню протягом $6-8$ тижнів; гострий парез ступні; кауда-синдром.

До протипоказань відносимо: високе розташування крил клубової кістки, що унеможливлює виконання трансфорамінального доступу на рівні L5 - S1; наявність нестабільності хребтово-рухового сегмента на оперованому рівні; виражений центральний стеноз хребтового каналу; далека краніальна або каудальна міграція вільного секвестру.

\section{Висновки}

1. Застосування трансфорамінальної ендоскопічної мікродискектомії в лікуванні 290 пацієнтів з грижами МХД підтвердило досить високу ефективність даної методики. Відповідно до міжнародного опитувача якості життя Oswestry середній показник щодо прооперованих пацієнтів становив 21,1\%, що відповідає доброму результату. Больовий синдром перед операцією був оцінений за ві- зуально-аналоговою шкалою у 8,5 бала, а через 6 міс після операції - у 1,5 бала (переважала люмбалгія і майже не було корінцевого болю).

2. Апробацією даної методики лікування пацієнтів з грижами МХД виявлені такі ії переваги: мінімальне пошкодження м'яких тканин та мінімальний контакт з нервовими структурами; швидке післяопераційне відновлення, що скорочує тривалість періоду непрацездатності; коагуляція епідуральних судин із застосуванням радіочастотного електрода з робочою температурою до $42{ }^{\circ} \mathrm{C}$ зменшуе ризик епідурального фіброзу на відміну від стандартного електрокоагулятора; хороша візуалізація внурішньоканальних структур під оптичним збільшенням зменшує ризик пошкодження нервового корінця; прямий доступ до екструзії через природний форамінальний отвір; мінімальний ризик виникнення інфекційних ускладнень.

\section{Підтвердження}

Інформація про фінансування.

Джерелом фінансування наукової роботи і публікації статті є приватні особи.

\section{Внесок авторів}

Всі автори внесли однаковий внесок в цю роботу.

Всі автори прочитали та схвалили остаточний варіант рукопису.

\section{Конфлікт інтересів}

Автори декларують відсутність конфлікту інтересів.

Згода на публікацію

Всі автори дали згоду на публікацію цього рукопису.

\section{References}

1. Kambin P. Arthroscopic microdiscectomy. Minimal interventionin spinal surgery. Baltimore: Urban and Schwarzenberg; 1991. 148 p.

2. Caspar W. A new surgical procedure for lumbar disc herniation causing less tissue damage through a microsurgical approach. Advances in Neurosurg. 1977;4:74-7. doi: 10.1007/978-3-642-66578-3_15.

3. Kambin P. History of disc surgery.Arthroscopic microdiscectomy. Baltimore; $1991.86 \mathrm{p}$.

4. Hoogland T, Schubert M, Miklitz B. Transforaminal posterolateral endoscopic discectomy with or without the combination of a low-dose chymopapain: a prospective randomized study in 280 consecutive cases. Spine (Phila Pa 1976). 2006 Nov 15;31(24):E890-7. doi: 10.1097/01. brs.0000245955.22358.3a.

5. Rutten S. Endoscopic lumbar disc surgery. Manual of Spine Surgery. Springler, Heidelberg, New York, Dordreccht, London.2012. 303 p. doi: 10.1007/978-3-642-22682-3_43.

6. Ahn Y, Lee S. Outcome predictors of percutaneous endoscopic lumbar discectomy and thermal annuloplasty for discogenic low back pain. Acta Neurochir. 2010 Oct;152(10):1695-702. doi: 10.1007/s00701010-0726-2.

7. Wang H, Huang B, Li C, Zhang Z, Wang J, Zheng W, Zhou Y. Learning curve for percutaneous endoscopic lumbar discectomy depending on the surgeon's training level of minimally invasive spine surgery. Clin Neurol Neurosurg. 2013 Oct;115(10):1987-91. doi: 10.1016/ j.clineuro.2013.06.008.

8. Rutten S, Komp M, Hanh P. Decompression of lumbar lateral spinal stenosis: full - endoscopic, interlaminar technique. Oper Orthop Traumatol. 2013 Feb;25(1):31-46. doi: 10.1007/s00064-012-0195-2.

9. Ruetten S, Komp M, Merk H, Godolias G. Recurrent lumbar disc herniation after conventional discectomy: a prospective, randomized study comparing fullendoscopic interlaminar and transforaminal versus microsurgical revision. J Spinal Disord Tech. 2009 Apr;22(2):122-9.doi: 10.1097/BSD.0b013e318175ddb4.

Отримана 08.08.2018 